Philosophy and Progress: Vols. LXI-LXII, January-June, July-December, 2017 ISSN 1607-2278 (Print), DOI : https://doi.org/10.3329/pp.v61i1-2.44204

\section{ROLE OF INTERFAITH DIALOGUE IN CHECKING RELIGIOUS EXTREMISM}

\section{Fazrin Huda*}

\begin{abstract}
The concept of interfaith dialogue is extremely significant in today's world. It is not a new concept. It has a historical and pragmatic significance. Religious extremism is a new threat to the world. Unfortunately, no one in this world is free from the threat of religious extremism and violence. This article adopts a qualitative approach and data are collected from both primary and secondary sources. This paper explores the role of interfaith dialogue to check religious extremism by taking interviews of seven respondents. It also argues that interfaith dialogue is very effective to check religious extremism along with the challenges of conducting an effective dialogue. These challenges may include the lack of proper knowledge of interfaith dialogue, prejudice of stereotypes religious ideas, misinterpretations and political misuse of religions, some common obstacles of conducting an interfaith dialogue. Last of all, the article also shows how the situation of Bangladesh can be improved through interfaith dialogue where there exists a combined effort from both common people and the government to check religious fanaticism and extremism.
\end{abstract}

\footnotetext{
* Associate Professor, Department of World Religions and Culture, University of Dhaka. E-mail: fazrinhuda.wrc@gmail.com
}

\section{Introduction}

The term religious extremism has always been defined with controversies and contentions. The multiple points of views and approaches are found to explain the aforementioned term. Despite great debate and controversies, it is often argued that the term religious extremism involves intolerant behavior towards other religions. When someone possessing a certain faith carries a hostile attitude towards the people following other faiths and deliberately causes harm to them that state of aggressive attitude is known as religious extremism. While religious extremism is threatening national security and peace throughout the entire world, global war has been declared against religious extremism and terrorism.

As religion is used and abused behind the rise of many terrorist movements, the paper intends to unveil the role of interfaith dialogue as a strategy, approach and necessary measure to fight against religious extremism. In this regard, the socio-political history and religious discourse of Bangladesh have been presented in the research article as a case study. This case study would demonstrate how religion gets amalgamated with political factors and open the scope for the rise of religious extremism.

\section{Objectives and Rationale}

As this study aims to find out the role of interfaith dialogue in order to control the wave of religious extremism, this work depends on the following objectives:

1. To discover the root causes of religious extremism in Bangladesh.

2. To find out the features of interfaith dialogue.

3. To explore the role of interfaith dialogue to resist and control religious extremism in Bangladesh. 


\section{Methodology and Data Collection}

In order to understand interfaith dialogue and its influences on people's cognitive aspect and society, a great understanding of knowledge is required. In this article primary and secondary sources have been used to collect relevant data and information regarding the phenomenon of religious pluralism and interfaith dialogue. Relevant books, journals, reports, online based articles have been used to collect the secondary data. Seven respondents, on the other hand, were selected for semistructured interview. All respondents of this qualitative research work are university professors and students. As the subject is religiously sensitive and politically touchy, anonymity has been maintained and pseudo names have been used in case of identification of the respondents.

\section{Literature Review}

In order to conduct this research work, the researchers have reviewed a good number of scholarly books, articles, papers to get conceptual clarity regarding the phenomenon of religious extremism, interfaith dialogue etc.

By considering religion not exclusively as a closed phenomenon Raimond Panikkar (1999) focuses on the growth of religions through dialogue in his research work entitled The Interreligious Dialogue (1999). As religions according to his analysis cannot be explained entirely by theology or divinity, they are constantly changing countenances. Accordingly, interaction among various religions and interfaith dialogue can assist them to grow. In his study, Raimond emphasizes on the methodological outline of interfaith dialogue. From his analysis he draws the conclusion that a religious phenomenology is required to make an interfaith dialogue successful. When more than one person or group maintain the same level of thought process the interreligious dialogue among them turns to intra- religious dialogue as the inner selves of various religions and faiths encounter. Interfaith dialogue is consequently pretty helpful for the development of different religions.

In the research work The Age of Global Dialogue, Leonard Swidler (2016) analyzes the concepts of 'inner' and 'inter' faith dialogue and elaborately explains the terms religion and dialogue. His practical and theoretical versions of interreligious dialogue have been revealed in his another work The Dialogue Decalogue. In this work, he highlights the importance of the discourse of dialogue among the communities of different faiths and cultures to stand against the communal approach. New methods should be opened for better religious perspective by using Deep-Dialogue, Critical Thinking, Emotional Intelligence and Competitive Co-operation (DCEC) among different faiths and religions. Regulating 'Deep-Dialogue' among individuals or groups pertaining different faiths and beliefs, it is possible to re-shape their thought process in multiple ways.

The book Pope John Paul and Interreligious Dialogue (2005), brings into focus the importance of interreligious dialogue from the Catholic perspective. In editing the book Byron I, Sherwin and Harold Kasimow reveal the view of Pope John PaulII and other scholars regarding Islam, Buddhism and Judaism. Pope John Paul II felt the importance of interreligious dialogue in understanding other religions properly.

In his work, Being Religious Interreligiously: Asian Perspectives on Interfaith Dialogue, Peter C. Phan (2004) focused on reciprocation among postmodernism, pluralism and interfaith dialogue. The world is now experiencing religious post modernity which promotes religious and cultural pluralism. In this era of post modernism interreligious dialogue is needed to the world where complexities of religious 
pluralism persist. He turns his focus on practical implication of interfaith dialogue.

Among the Bengali religious scholars Islam and Islam (2002) in their book Tulana Mulak Dharmatatva: Naitikata $O$ Manav Kallyan have explored the nature, scope and necessity of interfaith dialogue with the most illustrated definition of religion. The book mainly contains the essence of interfaith harmony among Sikhism, Shinto, Hinduism and Buddhism. The philosophical aspects of Shankara and Gautama Buddha have also been narrated in this text.

Ali Riaz (2017), as a political scientist, has critically analyzed the role of religion in public sphere and its contributions to political activism and election mannerism in the context of Bangladesh society. The rise of Islamic militancy in Bangladesh and Madrasa education system have been explored in his book, where an attempt was taken to give an overview of the contemporary situation of Bangladesh and its political sphere where religion plays a vital role.

\section{Conceptual Points}

\section{Definition, Nature and Scope of Interfaith Dialogue}

Interfaith dialogue is the conversation between two or more people of different faiths and religious groups who share their ideas and philosophies with each other. The motive of interfaith dialogue is to establish co-operations, peace and mutual understanding despite of sharp differences in religious faiths and rituals (Islam, 2011). It encourages tolerance and acceptance that mutual harmony is necessary for a peaceful world. The term interfaith dialogue denotes respect and mutual understanding. It is a very effective form of establishing peace and eradicating hatred and conflict (Islam \& Islam, 2002). It is not mandatory to organize interfaith dialogue in a formal way. Interfaith dialogue is a part of daily life. It can be happened between different levels such as among the neighbors, in schools, in colleges and universities.

This concept is fundamentally related to the concept of pluralism. This emphasis on the acceptance of the pluralistic approach of religion, that is giving approval to religious diversity. Pluralism is the opposite of inclusivism. Whereas inclusivism denotes turning of all faiths into one faith, Pluralism manifests the co-existence of different religions and heterogeneity of culture and society.

Interfaith dialogue is equally significant for the development of human self and its ethical behavior. Without it, "ethical behavior becomes frozen and eventually shatters. As a result, the self remains dwarfed and never becomes fully humanized." (Swidler, 2014, p. 34).

\section{Religious Extremism}

Although there is no concrete definition of extremism it is often explained with negative connotation. The term has been interpretedwith controversies and contentions as multiple points of views are found to explain it. Despite a great socioreligious debate it is often argued that extremism does not support freedom of expression and freedom of choice. This kind of philosophy negates all kinds of liberal thoughts and operates as an anti-thesis of human and civil rights (Cronin, 2008). Those who nourish the thesis of extremism is identified as extremist. The extremists consider their philosophy entirely correct and accordingly want to impose their philosophy on others either unquestionably or through violence, if needed. Extremism in their view is the only way through which better future could be achieved. 
As extremism involves several motives and objectives including religious, political, cultural etc., the extremists use several propagations, financial assistance as well as strategies including force, violence, threat or horror, to attract the youths, minorities, financially and educationally impoverished to believe that they are being deprived and should protest against this. Extremism, accordingly, is considered as an ideology, a strategy and a technique which operates to fulfill pre-designed objectives.

Religion has been the stimulation of extremism for many persons and groups who consider their identities exclusively through religious ideologies. In their imaginations, only their religion is placed in supreme position (Lutz \& Lutz, 2008). This kind of perspective is considered as the monolithic view of religions. By nullifying and voiding other faiths, the religious extremists believe in only one religion. However, religious extremism can exist in and out the monolithic religious traditions. In Islam there can be religious extremism even though they follow the same one God, Allah and same religious text, Qur'an. In Christianity there exists religious extremism among the different denominations.Religious extremism causes inter and intra-religious conflict. By violating the basic teachings of religions, it creates panic and traumatic condition within the religious groups.

\section{Rise of Religious Extremism in Bangladesh}

Bangladesh emerged on the basis of Bengali nationalism in 1971 by breaking the tie with Pakistan. Bengali nationalism is a linguistic one based on cultural nationalism which negates the philosophy of Muslim Nationalism of Pakistan. By shattering the Muslim Nationalism of Pakistan, Bangladesh emerged as a secular, modern democratic state under the leadership of Bangabandhu Sheikh Mujibur Rahman. In post 75 period the military discourse contributes to make Islam as the primary stimulant to determine the discourse of politics (Huda, 2008). Instead of the principles of secularism and Bengali nationalism as country's culture, heritage and history have been explained in the light of discourse of religiosity. The late Bengali scholar Muhammad Kabir argues that Maj. General Ziaur-Rahman, who seized power in the mid 1970s, "successfully changed the image of Bangladesh from a liberal Muslim country to an Islamic country (Kabir, 1994, p. 201)." Indeed, the Bengali term for secularism is Dharma Nirapekshata, which literally translates to "religious neutrality." Thus, the word "secularism" in a Bangladeshi context has a subtle difference in meaning from its use in the West (Kabir, 1994, p. 201). In 1977, Zia dropped the term 'secularism' from the fore cornerstones of Bangladesh constitution.

As Zia was enthusiastic in transferring Bangladesh into Islamic polity, he amended Constitution by introducing Bismillah in it and affirmed that the country will build up a strong rapport with Muslim world. Along with this amendment, Zia equally repealed the article 38 of the Bangladesh Constitution due to which religion based political parties and a group of pro-Pakistani people including Shah Aziz and Matiur Rahman received new political life under his military rule (Huda, 2004).

In 1988, by following the path of Zia, Lt. General Hossain Muhammed Ershad (1982-90) made Islam the state religion of Bangladesh, changed the holiday from Sunday to Friday. Whereas Zia lifted the ban on religion based political parties, General Ershad contributed to revive the Jamat-e-Islami to challenge the philosophy of secularism. Jamat-e-Islami was one of the anti-liberation war parties which got the opportunity 
to re-surface in Bangladesh politics. By conducting an extensive research on the economic base of fundamentalist groups, Professor Abul Barakat revealed how Jamat built its strong socio-economic and cultural base within the discourse of militarism and financial patronizations of Saudi Arabia and Middle East countries (Barakat, 2018).

\section{Findings}

\section{Role of Interfaith Dialogue inChecking Religiou Extremism}

Indeed, by analyzing the views and opinions of the respondents the researcher observes that religion itself seldom contributes as a dominant or driving force to the violent behavior. Religious interpretations rather play the role as a primary tool for perpetuating terrorist groups and extremist, either openly or clandestinely. While religious interpretation is used as a pretext for justifying the translation of grievances into violence, the respondents of this research work argue that the religious leaders and mass as well as print media could control these wrong narratives of religion in the light of correct narratives of their own religious text to control violence, division and culture of hatred.

Thus, one of the respondents ' $A$ ' emphasizes on interfaith dialogue in order to eradicate and decrease religious extremism. However, she asserts that, it is not the only way and interfaith dialogue alone cannot check religious extremism. He considers religious extremism as a social phenomenon and it cannot be tested in a laboratory to find out the exact causes. Under the circumstances, the role of social media should be constructive and moral degradation must be stopped. Otherwise, she opines, society will be deprived of getting the effective result of interfaith dialogue in controlling religious extremism.
According to respondent ' $\mathrm{B}$ ', a culture of interfaith dialogue should be developed in our society if it is patronized by government with an end in view to stop religious extremism. According to her analysis, it is possible that interfaith dialogue can play a major role in checking religious extremism. Respondent ' $C$ ' and ' $D$ ' hold the same view that interfaith dialogue should be patronized and preached through government in every sector of a country to utilize and get its nectar of religious harmony.

Respondent ' $E$ ' considers interfaith dialogue as a very effective medium to check religious extremism. According to ' $E$ ', religious extremism is such a philosophy which is patronized by some fanatic people through the process of brainwashing. Misinterpretation and misconceptions of religious value contribute a lot to misguide. Since through interfaith dialogue one can know other and understand other's religious point of view, it can help to remove those fanatic ideas and extremist views.

\section{Challenges of Interfaith Dialogue}

The researchers have been successful to find out the challenges of interfaith dialogue through this work. Indeed, from the narrative of respondents the researcher discovers that the challenges of interfaith dialogue are many and various. One of the major challenges of interfaith dialogue is that it remains confined within a small group particularly among the religious or academic scholars. As Mass people remain unaware of it, the effectiveness of interfaith dialogue go in vain. By pinpointing on this aspect, the respondent ' $A$ ' argues that the term 'interfaith dialogue' is an academic term and only few persons are aware of that. A shop-keeper or a house wife doesn't have the idea of interfaith dialogue. Even many persons of high rank are not clear about the meaning and role of interfaith dialogue. 
This term, he finds is not frequently used in public and private life. The term remains equally absent in social media or mass media where mass people could be directly connected with this phenomenon. Abuse of religion and political use of religion are the main challenges and obstacle in the way of interfaith dialogue, respondent ' $A$ ' added.

Most of the people are influenced by their local religious leaders and family religious traditions, respondent ' $\mathrm{B}$ ' asserts. Both religious dogmas and stereotype beliefs play the crucial role to develop their psychological set up. Because of having such mind set, it is very difficult to bring change in their cognitive aspect through interfaith dialogue. This orthodox people accordingly do not get interest to take part in dialogue with an open mind.

Another main impediment in the flourishment of interfaith dialogue is loopholes in education system of Bangladesh. Education system of Bangladesh, the respondents find often remains silent in patronizing interfaith dialogue. By considering it as the root cause of the failure of interfaith dialogue, they cited the examples of textbooks of religions which have been written exclusively either for Hindus or Muslims or Christians. Under the circumstances, the students of different religious groups get the opportunity to know their personal religion but remain unaware about other religious philosophies. Thus, according to the respondent ' $\mathrm{D}$ ', the coexistence of several kinds of education system is very dangerous for Bangladesh. As the religious schools including Madrasas specially Qwami Madrasa keep aloof from the teaching of secularism, he asserts, the students of this sector are totally unaware of different religions and they have many misconceptions in their mind.

\section{Role of Interfaith Dialogue in Combating Extremism}

In order to combat with extremism, the government, law enforcing authorities, family institutions and political parties of Bangladesh, the respondents assert must work collectively to fight against the extremist forces of Bangladesh. The concept of extremism, the respondents argue cannot be considered exclusively as a theoretical phenomenon. In their conceptualization it remains simultaneously as socio-religious and psychological phenomena. Misinterpretations of religions, global politics, rise of Jihadi movement across the globe, political instability, and vulnerable condition of democracy have been identified by the respondents as the main contributory factors behind the emergence of religious extremism and conflicting situations of Bangladesh.

According to respondent ' $\mathrm{A}$ ', thus, the political conflicts create frustration as well as platform for flourishment of extremist groups. Respondent ' $B$ ' reveals the role of the political leaders who did the great mistake in the past by declaring Islam as state religion and negating the philosophy of secularism and freedom for all religious groups. In order to overcome such conflicting situation, he highlights the role of government by expressing that it should promote the philosophy of religious freedom and must act neutrally to ensure equal treatment to all religions in Bangladesh.

Respondent ' $\mathrm{C}$ ', suggests that the concept of interfaith dialogue should be nurtured and spread among the common people. This idea should be included in the text book by the government. It is the holy task of the government to patronize those departments or educational institutes that organize and support interfaith dialogue and interfaith harmony. 
Educational institutions according to respondent ' $E$ ' can play a great role to curtail the strength of extremist force. As Bangladesh in his imagination is not a fertile land for the cultivation of extremist views and philosophy, academic curriculum and syllabus must be designed with the spirit of secularism, pluralism and interfaith dialogue. Indeed, he argues it is the task of the government to establish more institutions and departments to teach all religions with equal respect in the light of ancient history, philosophy and cultural traditions of Bangladesh. This scientific attempt, he opines, will help the students to negate the philosophy of extremism as well as to develop a constructive and effective understanding of religions.

\section{Concluding Remarks}

By analyzing the views and opinions of the respondents it can be said that religion in its truest sense cannot be a source of conflict. It is not religion but misinterpretations of religion, power politics, global Jihadi movement are now contributing to open the path of militancy and extremism in Bangladesh. Although many factors can play positive roles to restrain the people from taking the dangerous path of extremism, this paper has brought into focus the role of interfaith dialogue as a strong medium to combat with extremism and radical ideologies. Despite some challenges and limitations, interfaith dialogue can be an effective tool to fight against religious extremism.

The concept of interfaith dialogue accordingly should be patronized globally and nationally. It should be publicized from public to private domains. While communal harmony, philosophy of pluralism, humanism and secularism are the striking features of Bengali culture, through the proper use of interfaith dialogue Bangladesh could again be a model of interfaith harmony and religious freedom. In order to eradicate the political abuse of religion, the notion of interfaith dialogue should be cultivated through the process of learning from the primary level. The role of mass media could be equally effective in this regard. Personal communication and exchange of religious views among different faiths is also needed for the development of non-communal atmosphere in the society.

\section{References}

Ali, Zulficar, (2001), Manab Kalyan, Dharmo Nirapeksata o Tulanamulak Dharma: Ekti Darshanik Shamiksa (Human Welfare, Secularism and Comparative Religion: A Philosophical Survey), Bangladesh Asiatic Society Journal, vol.19, no 2, p. 166.

Ashraf, Ali, A.S.M., (2014), Explaining Recent Intelligence Reforms in Bangladesh, Journal of the Asiatic Society of Bangladesh (Hum.), 59 (1): pp. 65-94.

Barakat, Abul, (2018), Fundamentalism in Bangladesh: External and Internal Dimensions of Political Economy of Militancy: Dhaka: Mukta Buddhi Prokashana

Cronin, K.A. (2008), Behind the Curve: Globalization and International Terrorism. In Global Terrorism, edited by Lutz B.J. and Lutz J.M., Vol.1, London: Sage Publications. pp. 5776.

Cornille, Catherine (2013), The Wiley-Blackwell Companion to Inter-Religious Dialogue, USA: Wiley-Blackwell

Islam,Nurul Kazi, Islam Azizunnahar, (2016), Tulanamulak Dharma, Naitikata O Manab Kallyan (Comparative Religion, Morality and Welfare of Human being), Dhaka: Sangved

Islam, K.N., (2011), Interreligious Dialogue: Some Rules and Assumptions, Dialogue \& Alliance Vol. 25, No. 2, New York. Islam, K.N., (2013), The Qur'anic Message of Universalism and Religious Pluralism, Dialogue \& Alliance, Vol. 27, No. 2, New York. 
Interfaith Dialogue on Violent Extremism (iDOVE) (n.d.). African Union. Retrieved from https://au.int/en/pressreleases/20170223/ interfaith-dialogue-violent-extremism-idove (accessed Jnauary 2, 2018)

Kabir, Muhammad Ghulam., (1994), Changing Face of Nationalism: The Case of Bangladesh. New Delhi: South Asian Publishers

Lutz B.J. and Lutz J.M., (2008), Terrorism in a Global Setting (editors Introduction). In Global Terrorism edited by Lutz B.J. and Lutz J.M. Vol.1, London: Sage Publications. p. XXIXXXVIII.

Máire, Byrne, (2011) The Names of God in Judaism, Christianity and Islam: A Basis for Interfaith Dialogue, London Bloomsbury Academic; Continuum

Patel, E. and Brodeur, (2016), Building the Interfaith Youth Movement: Beyond Dialogue to Action. New York: Rowman and Littlefield

Riaz, Ali, (2017), Lived Islam \& Islamism in Bangladesh, Dhaka: Prathoma Prokashan

Twiss, Sumner, Grelle, Bruce (1999), Explorations in Global Ethics: Comparative Religious Ethics and Interreligious Dialogue, USA: Westview Press

Vatican Council, Nostra Aetate (Declaration on the Relationship of the Church to Non-Christian Religions, 1965. 